\title{
Towards a genetic model - the Ventersdorp alluvial diamond deposits (South Africa)
}

\author{
T.R. Marshall ${ }^{1}$, G Norton ${ }^{2}$ \\ ${ }^{1}$ Explorations Unlimited, Johannesburg, South Africa \\ ${ }^{2}$ Rockwell Diamonds Inc. Johannesburg, South Africa
}

The alluvial diamond fields of the North West Province extend over an area of some $25,000 \mathrm{~km}^{2}$. The total reported production from these diamond fields from 1904-1984 is estimated at 14.4 million carats (Marshall, 1987), which would have a present day value of over USD 5 Billion.

Early depositional models for the Ventersdorp deposits long recognised that the gravel deposits have been intimately associated with the development of the dolomitic karst wallrock and the subsequent subsidence of sinkholes. Much debate, however, has raged around the mode of deposition of the gravels within the karst system. Fundamental to all the models is an understanding of karst geology and development. Solution is not always the prevalent process in karst, nor is it necessarily the dominant one, but it does play a more important role here than in other kinds of landscapes. Its most critical effect lies in the enlargement of underground voids, causing increased permeability of the rock. As more water passes through the rock, the voids grow to become caves. Greater solubility of a substance is accompanied by a greater liability for the dissolved load to come out of solution, so chemical deposition can contribute in an important way to landform building in karst terrain, both on the surface and underground.

In karst areas, the total or partial absorption of a watercourse typically occurs through a swallow-hole or sinkhole. An important group of swallow-holes are those in which the disappearance of the river is marked by a conspicuous hole (typical of areas of present- and recent- glaciation). Dolines, or closed depressions of simple form, are exceedingly common and important in karst terrain. They are generally circular or oval in plan, with a range of forms; dish and bowl-shaped, conical and cylindrical. In size, dolines vary from a few metres in their dimensions to more than a hundred metres in depth and to several hundred metres in horizontal dimensions. A number of processes may be involved in the formation of dolines, including solution at or near the surface, cave collapse, piping and subsidence. These processes often work in combination or in sequence to form complex features.

The karst of the North West Province is perhaps unique in the world, due to the peculiar composition of the rock involved and probably also to its climatic history. The dolomite in the North West Province has undergone at least four periods of karstification since its deposition in the Proterozoic (Martini, 1975):

- Pre-Pretoria Group (Giant Chert)

- Pre-Waterberg Group (dissolution cavities in the dolomite, filled with red Waterberg sandstone)

- Pre-Karoo Supergroup (the karst forms suggest development under a cold climate as may be expected from the associated glacial deposits);

- Tertiary-Recent: (by early Tertiary times it is conjectured that the Karoo cover in this region was sufficiently thin (and absent in places) to allow for the evolution of a karst landscape.

It is fundamental to the model to appreciate that the gravels were deposited in a karst system where:

- the dolomitic bedrock contacts with the gravels may be vertical;

- the mode of gravel deposition is not typical fluvial-alluvial;

- periodic subsidence/collapse has taken place during deposition;

- deposition has taken place over a long time (at least since the Mesozoic), resulting in a build-up of a very thick gravel sequence.

The gravel runs are controlled by karst formation along linear, fracture or fault zones which allowed the increased flow of ground water that led to higher than normal levels of dissolution of the dolomites and resulted in the formation of sinkholes and channels. Some of the sinkholes are more than $100 \mathrm{~m}$ deep. The sedimentary infill of the sinkholes is variable and depends on the depth and subsidence history of each individual sinkhole.

Each sinkhole contains a composite sinkhole-fill succession of variable age, deposited sequentially in response to continuous sinkhole subsidence and deepening. The gravel fills young upwards in the succession and may steepen towards the edges of the sinkholes as a result of continued deepening and sidewall drag or shear. As a result, older gravels may extend up the sidewalls almost reaching the surface around the margins of the sinkhole. This causes individual geological units and even overburden to dip inwards and thicken towards the centre of the sinkhole. 


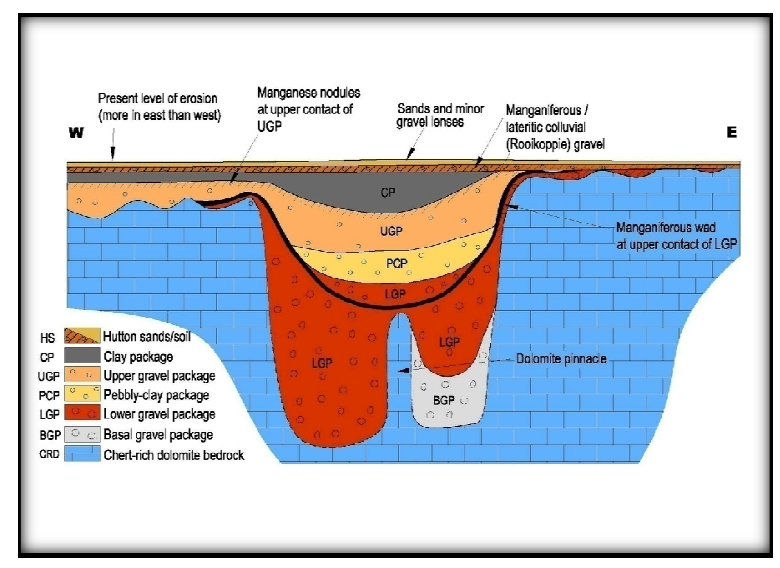

Lower Gravel Package (LGP)

The gravel is generally a clast-supported mixed unit. It is characterized by a much higher proportion of quartzite clasts than chert clasts. Also present are clasts of Waterberg arkose/sandstone, weathered Hekpoort andesites, and red diamictite (Pre-Waterberg cave infill) which are very distinctive. Typically, this unit has a concentration of manganese wad at its upper contact which is is likely of late Cretaceous age. These gravels generally carry elevated diamond grades and are the primary exploration targets where they exist. Locally developed are more clay-rich horizons - a consequence of spalling of the wallrock into the accumulating gravel pile. As a result of the increased clay content, these gravels are distinguished by lower, but still potentially economic, grades and increased processing problems. Towards the base of the profile in some of the deeper sinkholes a whitish Basal Gravel may occur, which appears to be a variation within the LGP which has been affected by local leaching.

\section{Pebbly Clay Package (PCP)}

This unit comprised of clays and pebble to small cobble lenses may reach thicknesses of $5-50 \mathrm{~m}$. It appears to be a fluvial unit which has reworked the underlying LGP units. Grades are very low and diamonds are small.

\section{Upper Gravel Package (UGP)}

This unit represents reworked LGP with the addition of locally derived, angular cherts. Not only do UGP's occur as sinkhole/channel infill but they also drape over the surface. With moderate grades (and generally lower mining costs) this unit is considered an economic horizon. A second phase of manganese (nodule) enrichment appears to be associated with the end of deposition of UGP.

\section{Clay Package (CP)}

A thick unit (up to $20 \mathrm{~m}$ ) of generally massive clay (with minor grit/pebble lenses) overlays everything as a sheet that gets thicker over potholes. It is a completely non-diamondiferous overburden.

\section{Hutton Soil}

The Hutton soil profile is comprised of a stone lag and overlain by windblown sands (locally termed Hutton Sands). The stone lag is a concentrate layer formed by post-depositional colluvial and eluvial processes.

\section{Geological/Morphotectonic Model}

During the lowered watertables and cold climates associated with the Dwyka glaciation (345 - 250My), subterranean solution by phreatic and vadose waters carved out an extensive drainage network in the dolomite plain. It is probable that the water derived from the melting Dwyka glaciers may have been the impetus that initiated the collapsing of many of the karstic sinkholes and dolines (especially as subsidence dolines). The channels in the Ventersdorp district appear to be allogenic (with their headwaters on the clastic rocks of the Pretoria Group). Most of the channels either follow lithologic boundaries (between the chert-rich and chert-poor dolomite strata) or structural features such as dykes, faults and joints.

The withdrawal of the glaciers saw the deposition of Dwyka tillite as a thin veneer of material on top of the dolomite plain. A raft of Dwyka shales preserved as cave infill indicates that Dwyka deposits in this area included shale. This was followed by the deposition of thin Ecca shales, remnants of which are still preserved in the cave to the west of Ventersdorp (Martini and Kavalieris, 1976).

Somewhere prior to the onset of the African landscape cycle the gravel on the dolomite plain must have become mixed with the diamonds (pre- or postglaciation is unclear at this stage). Since diamond characteristics, average grades and qualities/values (USD 500-700/ct) vary little across much of the dolomite plain (over an area of some $30 \times 100 \mathrm{~km}$ ), separate, localised primary sources cannot be the source of the diamonds. Studies are currently in progress to characterise this original diamond-bearing gravel and identify the provenance(s) of the diamonds.

After late Jurassic - early Cretaceous rifting of Gondwanaland lowering of the North West Province landscape resulted in exposing much of the pre-Karoo subterranean caverns to the surface. The surficial gravel was subsequently dumped into these early canyons and sinkholes (as BGP and LGP deposits) that were initiated at the surface as a result of a renewed karst cycle. The drainage channels, which appear to be partly subaerial and partly subterranean have their headwaters in the Pretoria Group sediments to the north. The subcontinental uplift had also resulted in lowered regional watertables. As a consequence, phreatic and vadose cavern development was initiated below the level of the surface drainage. 


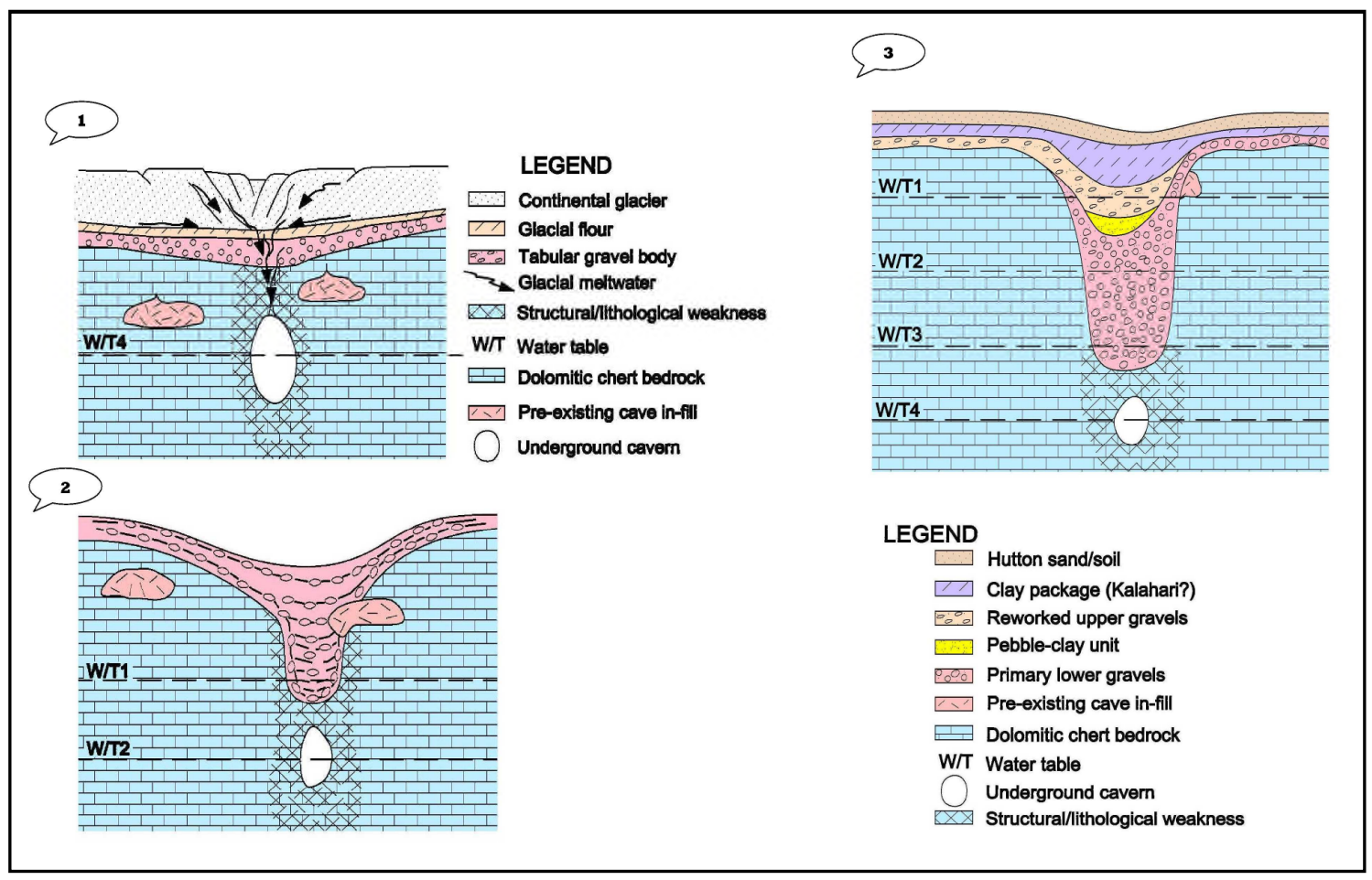

\section{Underground solution channels carved out by glacial meltwaters during the Palaeozoic followed by the enlargement of subterranean karst structures by subsidence and collapse.}

During the LGP depositional phase the deposits were moved by mass flow, with lots of water and very little, if any, reworking and re-concentration. It is thought that much of the initial deposition may have been subterranean. The subterranean karst structures would have been accessed and enlarged by a combination of subsidence and collapse. The LGP units are generally red in colour - this is thought to reflect the nature of the source rocks. The basal units (BGP), by contrast, are pale in colour and may be related to deep leaching during the early development of the karst system.

It is envisaged that deposition continued over an extended time period, to account for the great thicknesses seen in sinkholes

The African surface is known to be of polycyclic origin (Partridge \& Maud, 1987) and it is suggested that reworking associated with minor uplift episodes may have been responsible for the deposition of the Transition Gravels (TZP) and the PCP (Pebble-clay package) units.

The African landscape cycle was interrupted toward the end of the early Miocene $( \pm 18 \mathrm{Ma})$ by regional uplift (Partridge \& Maud, 1987). The UGP was deposited as a result of the reworking of the LGP unit, with a concomitant increase in local, angular chert content. This deposition is likely mostly subaerial since the gravels are not only found in the sinkholes/channels, but also spread out on the surface as "sheet gravels".
The Mio-Pliocene landsurface was terminated at the end of the Pliocene. During this time, the Clay (CP) Package was deposited as an extensive, sheet. Thickening of the clay unit over the potholes indicates that subsidence was still continuing. The depositional environment of the clay unit is envisioned as part of the prograding Kalahari succession. Subsequently, Pleistocene glacio-eustatic sea-level fluctuation resulted in the development of the colluvial gravel unit which is seen to cut across all of the outcropping units (CP and UGP).

\section{References}

Beukes, N.J, van Niekerk, H.S. and Gutzmer, J (1999): Post Gondwana African land surfaces and pedogenetic ferromanganese deposits on the Witwatersrand at the West Wits Gold Mine, South Africa. S. Afr. J. Geol., 102(1),65-83 De Wit, M.C.J, Marshall T.R. \& Partridge, T.C (2000): Fluvial deposits and drainage systems, p55-72. In, T C Partridge and RR Maud, The Cenozoic of Southern Africa. Oxford Monographs on Geology and Geophysics No 40. Oxford University Press, New York, 406pp

Marshall, T.R. (1987): Alluvial diamond occurrences of the Western and south- Western Transvaal - a compilation of production data. Inf. Circ. No 194, Econ. Geol. Res. Unit, Jhb. 200 pp.

Martini, J. and Kavalieris, I. (1976): The karst of the Transvaal (South Africa). Int. J. Speleol, 8, 229-251.

Partridge, T. C. and Maud, R.R (1987): Geomorphic evolution of southern Africa since the Mesozoic. S. Afr. J. Geol., 90(2), 179-208.

Stettler, E.H. (1979): A geological and geophysical investigation of the diamond runs on Ruigtelaagte and vicinity, in the Bakerville area, Lichtenburg district. Unpubl. MSc. thesis. Univ. Pretoria, Pretoria, 12Opp.

von Backström, J.W, Schumann, F.W, le Roex, H.D,Kent, L.E, and du Toit, A.L. (1952): Die Geolgie van die Gebied om Lichtenburg. Geol. Surv. 70pp. 